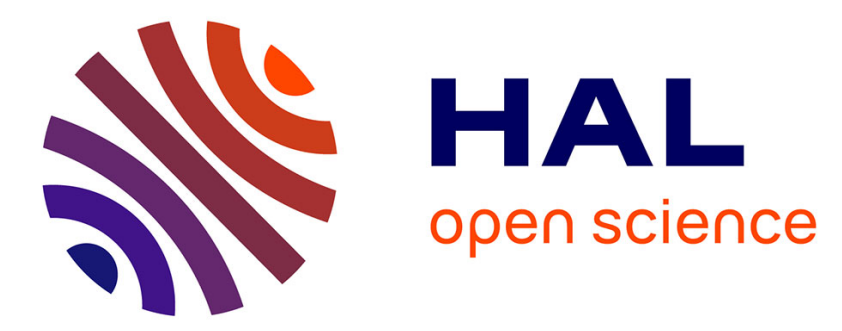

\title{
Sedimentary cannabinol tracks the history of hemp retting
}

Marlène Lavrieux, Jérémy Jacob, Jean-Robert Disnar, Jean-Gabriel Bréhéret, Claude Le Milbeau, Yannick Miras, Valérie Andrieu-Ponel

\section{- To cite this version:}

Marlène Lavrieux, Jérémy Jacob, Jean-Robert Disnar, Jean-Gabriel Bréhéret, Claude Le Milbeau, et al.. Sedimentary cannabinol tracks the history of hemp retting. Geology, 2013, 41 (7), pp.751-754. 10.1130/G34073.1 . insu-00781644

\section{HAL Id: insu-00781644 https://hal-insu.archives-ouvertes.fr/insu-00781644}

Submitted on 28 Nov 2019

HAL is a multi-disciplinary open access archive for the deposit and dissemination of scientific research documents, whether they are published or not. The documents may come from teaching and research institutions in France or abroad, or from public or private research centers.
L'archive ouverte pluridisciplinaire HAL, est destinée au dépôt et à la diffusion de documents scientifiques de niveau recherche, publiés ou non, émanant des établissements d'enseignement et de recherche français ou étrangers, des laboratoires publics ou privés. 


\section{Sedimentary cannabinol tracks the history of hemp retting}

3 Marlène Lavrieux ${ }^{1,2 *}$, Jérémy Jacob ${ }^{1}$, Jean-Robert Disnar ${ }^{1}$, Jean-Gabriel Bréheret ${ }^{2}$,

4 Claude Le Milbeau ${ }^{1}$, Yannick Miras ${ }^{3,4}$ and Valérie Andrieu-Ponel ${ }^{5}$

$6 \quad{ }^{1} I n s t i t u t$ des Sciences de la Terre d'Orléans, Université d'Orléans, ISTO, UMR 7327, 45071

7 Orléans, France; CNRS/INSU, ISTO, UMR 7327, 45071 Orléans, France; and BRGM, ISTO,

8 UMR 7327, BP 36009, 45060 Orléans, France

$9{ }^{2}$ GéHCo (GéoHydrosystèmes Continentaux), EA 6293, Faculté des Sciences et Techniques,

10 Université François-Rabelais de Tours, Parc Grandmont, 37200 Tours, France

$11{ }^{3}$ CNRS, GEOLAB, UMR 6042, Laboratoire de Géographique Physique et Environnementale,

124 rue Ledru, 63057 Clermont-Ferrand Cedex 1, France

$13{ }^{4}$ Clermont Université, Université Blaise Pascal, GEOLAB, Maison des Sciences de l'Homme,

14 BP 10448, 63000 Clermont-Ferrand, France

15 Institut Méditerranéen d'Ecologie et de Paléoécologie, UMR CNRS 6116 Université Paul

16 Cézanne, Bâtiment Villemin, BP 80, 13545 Aix en Provence Cedex 04, France

17 *Current address: Laboratoire des Sciences du Climat et de l'Environnement, CEA-Orme

18 des Merisiers, F-91191 Gif-sur-Yvette Cedex; E-mail: marlene.lavrieux@univ-fcomte.fr.

\section{ABSTRACT}

21 Hemp (Cannabis sp.) has been a fundamental plant for the development of human

22 societies. Its fibers have long been used for textiles and rope making, which requires prior 
23 stem retting. This process is essential for extracting fibers from the stem of the plant, but can

24 adversely affect the quality of surface waters. The history of human activities related to

25 hemp (its domestication, spread, and processing) is frequently reconstructed from seeds and

26 pollen detected in archaeological sites or in sedimentary archives, but this method does not

27 always make it possible to ascertain whether retting took place. Hemp is also known to

28 contain phytocannabinoids, a type of chemicals that is specific to the plant. Here we report

29 on the detection of one of these chemicals, cannabinol (CBN), preserved in a sediment

30 record from a lake in the French Massif Central covering the past $1800 \mathrm{yr}$. The presence of

31 this molecule in the sedimentary record is related to retting. Analysis of the evolution of

32 CBN concentrations shows that hemp retting was a significant activity in the area until ca.

33 A.D. 1850. These findings, supported by pollen analyses and historical data, show that this

34 novel sedimentary tracer can help to better constrain past impacts of human activities on the 35 environment.

\section{INTRODUCTION}

Hemp is one of the earliest cultivated plants (Russo, 2007). Its high adaptability

39 (Raman, 1998) allowed it to spread worldwide, perhaps through a co-evolution with

40 mankind (McPartland and Guy, 2004). Hemp can therefore be considered as a fundamental

41 plant in human history (Raman, 1998). Indeed the development of all civilizations has relied

42 on its many uses: e.g., as foodstuff (the seeds), medicine and intoxication (the resin), and

43 overwhelmingly for making ropes, textile, and paper (the fibers). The fibers are separated

44 from the stems after the retting process, usually consisting of submerging the stems in water

45 (Wills, 1998). Though retting is required for extracting fibers and is thus used worldwide, 
46 this traditional process has been known for centuries to dramatically damage water quality,

47 causing massive fish death and making water undrinkable for cattle and humans

48 (Anonymous, 1772). Tracing this ancient pollution is of major interest, because it can

49 provide clues to past interactions between human societies and environments, the

50 understanding of which is crucial to anticipate the consequences of future global changes

51 (Dearing, 2006). To date, pollen, seeds, or textile fragments are the only indicators currently

52 exploitable in archaeological studies to detect the use of retting (e.g., Schofield and Waller,

53 2005), and thus to assess the extent of the induced pollution.

$54 \quad$ Recording a continuous history of hemp retting can be achieved by using a set of

55 archaeological sites that are chronologically continuous and where seeds and pollen are

56 preserved, and implies morphometric analyses of pollen due to the resemblance between

57 Cannabis and Humulus (hop genus) pollen grains (Mercuri et al., 2002; Whittington and

58 Gordon, 1987). Moreover, pollen and seeds may be absent in archaeological sites (Wills,

59 1998). Monitoring tracers of human activity preserved in a natural archive can help

60 overcome these difficulties. The analysis of the molecular biomarker content of lacustrine

61 sediments (which continuously record environmental changes) and soils can provide

62 information on past environments, but only in a very few cases can these be unequivocally

63 related to human activity (e.g., Bull et al., 2002; Jacob et al., 2005, 2008; Zocatelli et al.,

64 2010; Lavrieux et al., 2011; Le Milbeau et al., 2013). Up to now, no study has revealed the

65 occurrence of any hemp biomarker in natural archives, although the plant contains

66 phytocannabinoids, a group of chemical compounds unique to this plant (Russo, 2007). We

67 here report on the detection of cannabinol in a sediment core drilled in Lake Aydat

68 (Auvergne region, France) that covers the past $1800 \mathrm{yr}$. 
70 METHODS AND STUDY SITE

\section{Sedimentary Core}

$72 \quad$ Lake Aydat $\left(45^{\circ} 39.809^{\prime} \mathrm{N}, 2^{\circ} 59.106^{\prime} \mathrm{E}\right)$ is located in the northern part of the French

73 Massif Central (Fig. 1), a volcanic region located in the center of France. A high-resolution

74 continuous sediment sequence covering the past $6700 \mathrm{yr}$ retrieved under $14.5 \mathrm{~m}$ water depth

75 was dated (accelerator mass spectrometry [AMS] radiocarbon dates, ${ }^{137} \mathrm{Cs}$ measurements,

76 and detection of historical flood deposits) and extensively described in a previous study

77 (Lavrieux et al., 2013). The present study focuses on the upper part of the core, consisting of

78 dark and faintly laminated sediment interrupted in many places by flood deposits. Samples

79 were selected in the background sediment, i.e., after the flood events were removed. Their

80 position is displayed together with the depth-age model in Figure 1. 


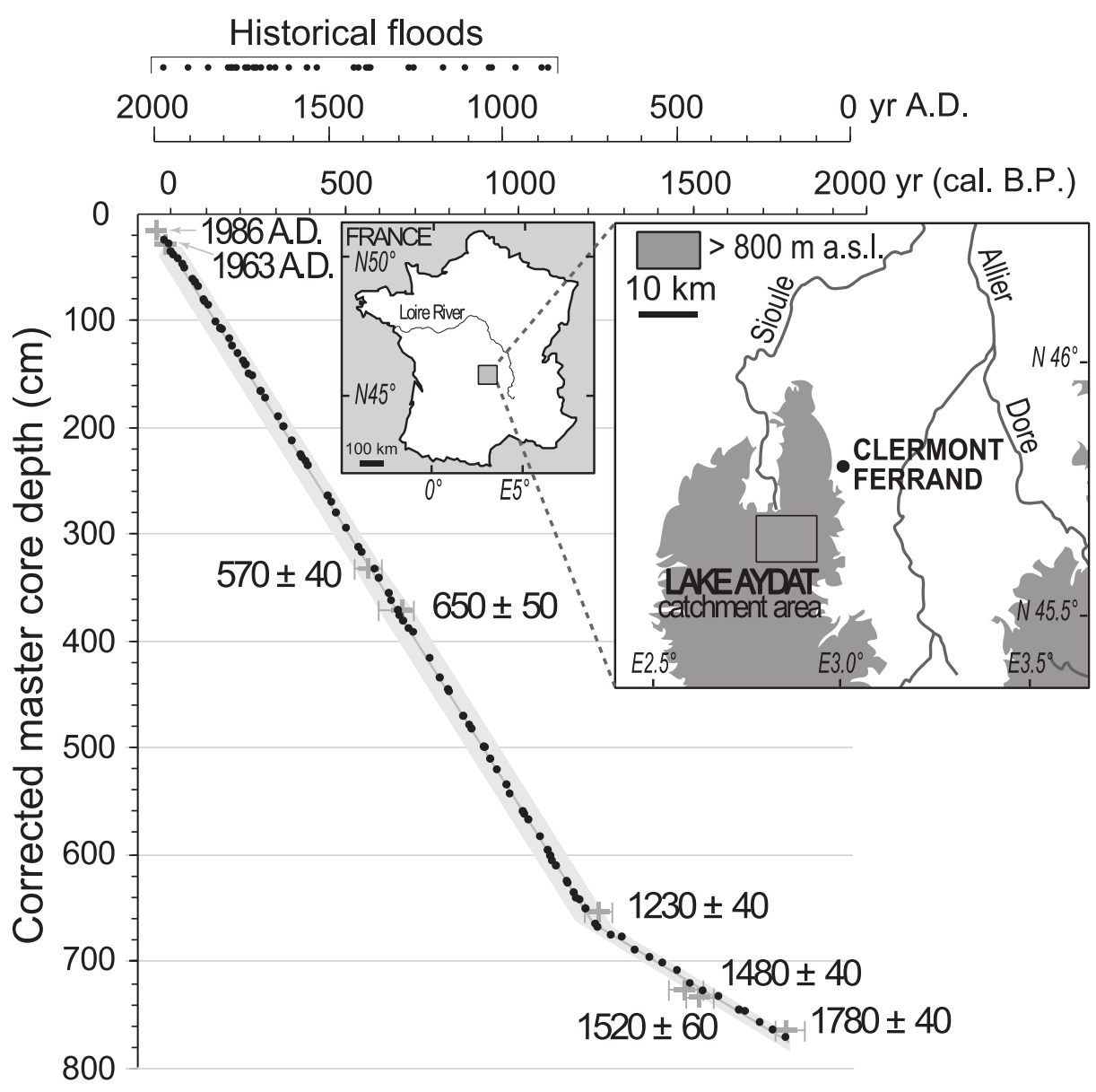

82 Figure 1. Location of study site in France, depth-age model (Lavrieux et al., 2013), and

83 position of sediment samples along sedimentary record. Corrected master core depth means

84 that flood deposits were removed. Accelerator mass spectrometry radiocarbon dates are

85 reported as calibrated years B.P. (before 1950) and shown as gray crosses and error bars.

86 Gray crosses without error bars are ${ }^{137} \mathrm{Cs}$ dates. Historical floods are shown above the

87 graphics. Reconstructed depth-age model is shown with a dark gray line (light gray-margin

88 of error). Sediment samples are symbolized with black dots. a.s.l.-above sea level. 
Pollen Analyses

91 Pollen analyses were performed on 50 samples, spaced $2.5 \mathrm{~cm}$ apart, covering the

92 past $1800 \mathrm{yr}$ (intervals of $35 \mathrm{yr}$ ). Samples were prepared using standard procedure (Faegri

93 and Iversen, 1989) at the Institut Méditerranéen de Biodiversité et d'Ecologie Marine et

94 Continentale (UMR 7263/CNRS, France). Minimum counts of 500 dry land pollen grains

95 per sample were made. Pollen rates were calculated as a percentage of total land pollen

96 excluding hygrophytes, aquatic plants, and fern spores. Morphometric analyses of pollen

97 grains were carried out according to Mercuri et al. (2002). The Cannabis-Humulus pollen

98 curve presented here combines the values of Cannabis-Humulus pollen type (pollen diameter

$9925-28 \mu \mathrm{m})$ and those of Cannabis pollen type (diameter $>28 \mu \mathrm{m}$ ). The frequencies of

100 Humulus pollen type (diameter $<25 \mu \mathrm{m}$ ) are excluded. The detailed pollen counts are

101 provided in the GSA Data Repository ${ }^{1}$.

102 Lipid Analyses

103 Sixty (60) lacustrine sediment samples covering the past $1800 \mathrm{yr}$ were dried, crushed

104 in a mortar, and sieved at $2 \mathrm{~mm}$. An internal standard was added to $\sim 1 \mathrm{~g}$ of sediment, which

105 was solvent extracted by automatic solvent extraction (Dionex Accelerated Solvent

106 Extractor) using a mixture of $\mathrm{CH}_{2} \mathrm{Cl}_{2}: \mathrm{MeOH}(9: 1 \mathrm{vol} / \mathrm{vol})$. After removal of the

107 solvent under $\mathrm{N}_{2}$, the extract was separated into neutral, acidic, and polar fractions on

108 aminopropylbonded silica. The neutral fraction was further separated into aliphatics,

109 aromatics, ethers and esters, ketones and acetates, and alcohols by flash chromatography on

110 a Pasteur pipette filled with activated silica, using a sequence of solvents of increasing

111 polarity. Alcohol fractions were then trimethylsilylated with N,O-bis (trimethylsilyl) 
112 trifluoroacetamide and pyridine $\left(2: 1 \mathrm{vol} / \mathrm{vol} ; 60^{\circ} \mathrm{C}, 60 \mathrm{~min}\right)$, and these fractions were

113 injected into a gas chromatography- mass spectrometry (GC-MS) system. The operating

114 conditions are detailed in Lavrieux et al. (2011). Cannabinol (CBN) was identified by

115 comparison with an authentic standard (also trimethylsilylated before injection) and its

116 concentration was estimated by measuring the area of its peak on an $\mathrm{m} / \mathrm{z} 367+382$ ion-

117 specific chromatogram. After calculating a correction factor between the peak area on the

118 ion-specific chromatogram and the peak area on the total ion current (TIC) chromatogram,

119 the TIC area of the compounds was compared to that of the standard ( $5 \alpha$-cholestane) and to

120 the mass of the sample extracted. The detailed CBN concentrations are provided in the Data

121 Repository.

122

123 RESULTS

124 CBN was identified in several alcohol fractions of the free lipids extracted from Lake

125 Aydat sediment samples. Its typical mass spectrum, molecular structure, and fragmentation

126 pattern (as trimethylsilylated derivative) are shown in Figure 2. 

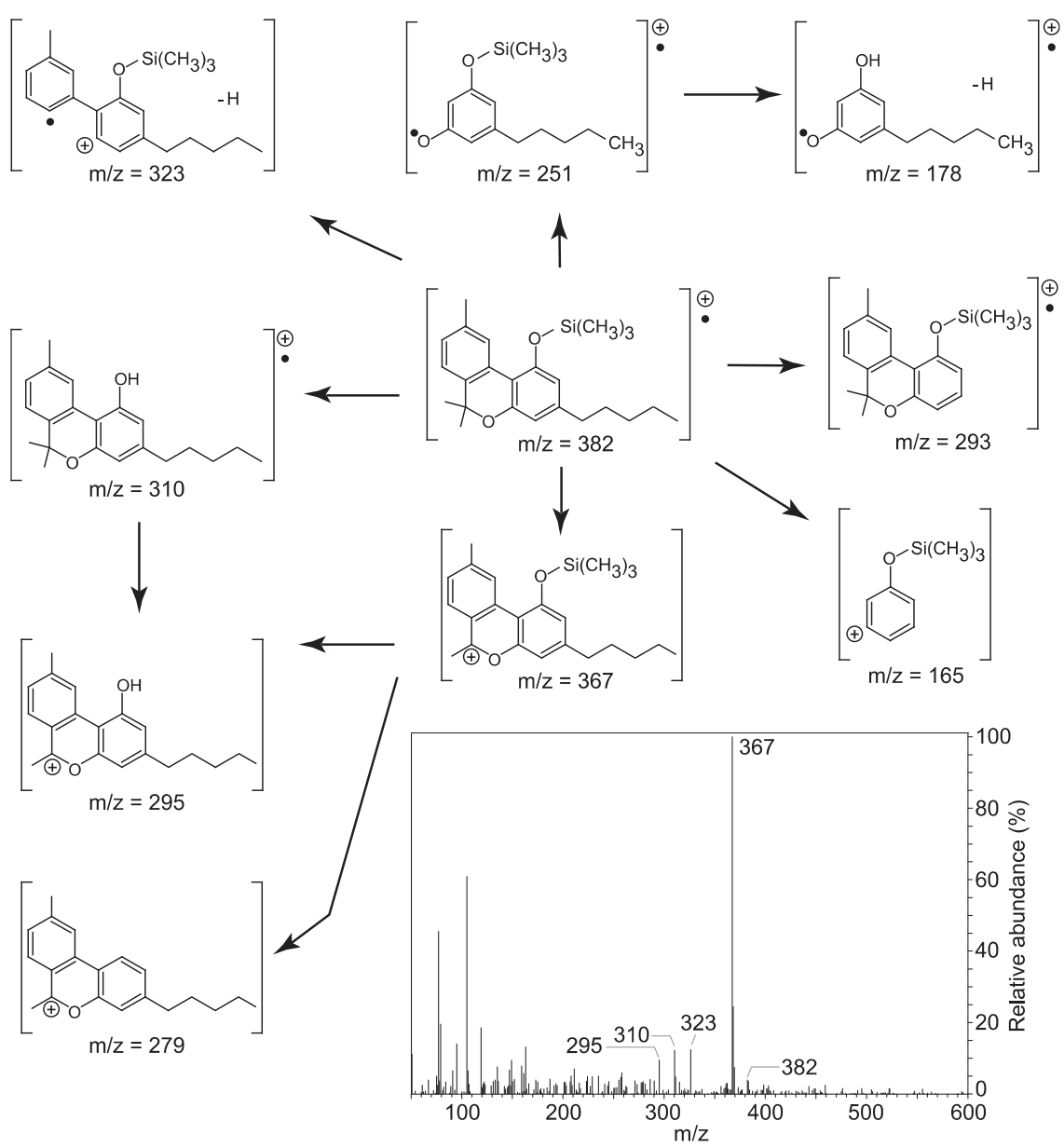

Figure 2. Mass spectrum and molecular structure of cannabinol (trimethylsilylated derivative) from selected sediment sample (A.D. 1322).

133 tetrahydrocannabinol ( $\Delta^{9}$-THC; ElSohly and Slade, 2005), a psychoactive compound whose

134 concentration in the plant differs depending on the variety of hemp considered $(<0.3 \%$ in

135 textile hemp versus >1\% for intoxicating hemp; Raman, 1998). 


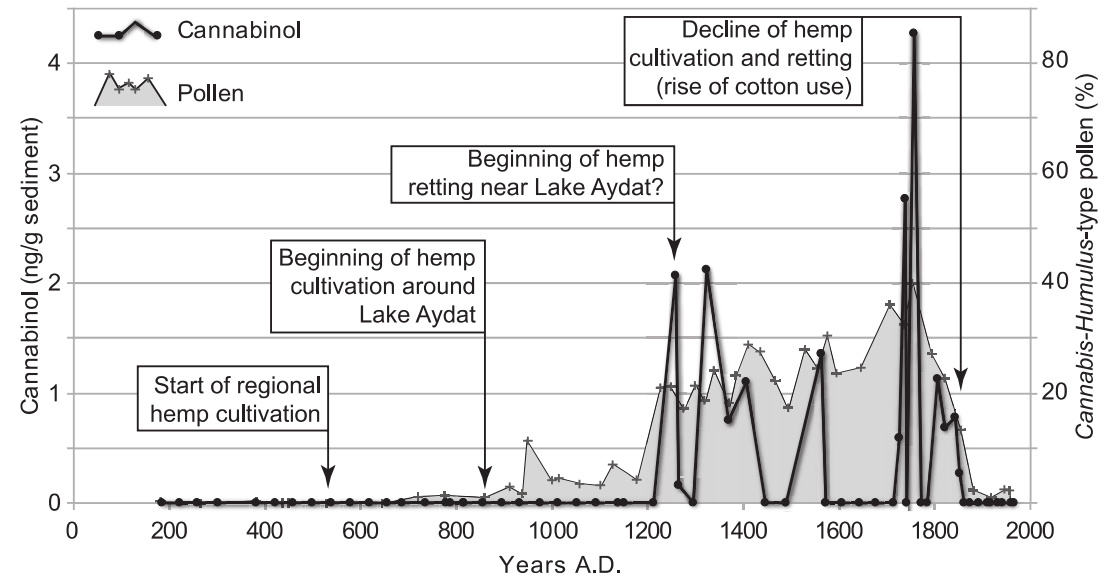

138 Figure 3. Evolution of cannabinol relative abundance (ng/g sediment) and of Cannabis-type

139 and Cannabis-Humulus-type pollen (expressed as a percentage of the total of terrestrial

140 pollen) through time in sediment samples. Main historical phases of hemp uses in the area are indicated in boxes.

144 samples (Fig. 3). Starting from the base of the studied section, Cannabis-type and Cannabis-

145 Humulus-type pollen was weakly present from A.D. 470, while CBN was detected for the

146 first time in sediments dated to ca. A.D. 1260, at concentration levels of $\sim 2 \mathrm{ng} / \mathrm{g}$ sediment.

147 From then on, $\mathrm{CBN}$ concentrations and pollen frequency varied strongly, and differently

148 from each other, all along the record. CBN was not detected in two samples dated from ca.

149 A.D. 1445-1490 and five samples dated from ca. A.D. 1570-1720, and maximized at A.D.

150 1757. Pollen frequency followed a more continuous trend, remaining under $~ 5 \%$ until ca.

151 A.D. 1200, when Cannabis-pollen-type values rose to almost 10\%, and then increased

152 abruptly to over $20 \%$. Overall, it remained between $\sim 20 \%$ and $30 \%$ - with a higher

153 proportion of Cannabis pollen type - until the end of the $18^{\text {th }}$ century, when it maximized at 
$154 \sim 40 \%$. From the beginning of the $19^{\text {th }}$ century, both CBN and pollen strongly decreased:

155 CBN was totally absent in sediments younger than ca. A.D. 1860, while pollen was still

156 weakly present $(\sim 2 \%)$ during the $20^{\text {th }}$ century. CBN was also absent in 35 soil samples

157 analyzed in the lake catchment (Lavrieux, 2011).

159 DISCUSSION

160 Fiber hemp was extensively cultivated in the Auvergne, France, region during

161 historical times (Peuchet, 1800), and was produced in small plots on the outskirts of every

162 village (Charbonnier, 1980). As in other regions, the main reason for producing hemp fibers

163 was for textile making (de Ballainvilliers, 1846), but all other parts of the plant, except the

164 roots, were used: oil (extracted from seeds) was used as lighting fuel and peeled stems were

165 used for heating (Poitrineau, 1965). Seeds were probably also consumed by local populations

166 and cattle, and leaves were probably used for animal bedding (Brown, 1998). Careful retting

167 was needed to produce a high-quality and reputed hemp fiber such as that used by the French

168 Royal Rope Factory for the marine arsenal, where the longest ropes in Europe (200 $\mathrm{m}$ all in

169 one piece) were made during the $17^{\text {th }}$ century (Peuchet, 1800). Hemp was also exported for

170 the paper industry (Peuchet, 1800). Thus, the numerous uses of hemp as well as its

171 widespread culture in the region explain the occurrence of one of its molecular biomarkers in

172 Lake Aydat sediments. Sedimentary CBN could originate either directly from the plant or

173 from hemp remains that were mixed in soils and subsequently eroded to the lake. Because

174 the whole hemp plant was used, most of the material likely to contain CBN was exported.

175 Only roots could constitute a potential contributor of soil CBN, but hemp roots have not

176 been shown to contain more than small amounts of cannabinoids (De Pasquale et al., 1974; 
177 Russo, 2007). Because soils are reputed to retain the molecular imprint of their past land

178 uses (Lavrieux et al., 2012), and although soils are the main contributors of terrestrial

179 organic matter to lacustrine sediments through erosion, another source must be invoked to

180 explain the presence of $\mathrm{CBN}$ in the lake sediments. The most obvious explanation involves

181 the practice of retting, a process largely used during historical times in Auvergne (Diderot

182 and d'Alembert, 1778; de la Platière, 1784) which consists of submerging the stems in water.

183 This was commonly done in all kinds of aquatic environments such as pits, marshes, ponds,

184 or rivers. The stems were then left in water for a few days to a few weeks in order to

185 facilitate extraction of the hemp fibers.

186 As stated above, pollen analyses conducted on the sediment core show the

187 continuous cultivation of hemp in the region from at least ca. A.D. 470 and in the catchment

188 from at least A.D. 870, and show a strong increase in pollen frequency between A.D. 1180

189 and 1860 (Fig. 3). Conversely, CBN concentration shows a more irregular pattern in this

190 time period and is not detected outside of it. Previous studies in the same catchment (Miras

191 et al., 2004; Lavrieux et al., 2013) revealed continuous human occupation associated with a

192 marked anthropic impact on the environment in the area throughout the time span

193 considered. While the absence of CBN before ca. A.D. 1260 could be explained by limited

194 cultivation (as suggested by the low pollen frequencies) and retting, leading to CBN

195 concentrations that are too low to be detected in the older samples, this hypothesis cannot

196 explain the significant differences observed between pollen and molecular signals for later

197 periods (A.D. 1445- 1490 and 1570-1720). Even though hemp pollen, which is

198 disseminated by wind (e.g., Small and Antle, 2003), could come, in part, from outside the

199 catchment (contrary to CBN, which is necessarily autochthonous), the high frequencies 
200 observed during this period leave no doubt concerning the reality of retting near Lake Aydat.

201 No relationship between these discrepancy phases and the different sedimentological

202 parameters expanded by Lavrieux et al. (2013) could be highlighted, underlining that the

203 molecular signal is not determined by the sedimentation rate and/or the dilution in the

204 mineral phase of the sediment. So, in the absence of any other tangible evidence, it can be

205 hypothesized that variations in environmental conditions (for example, intensity of exposure

206 to sunlight and/or of insect predation) known to influence phytocannabinoid concentrations

207 (e.g., Pate, 1994) could have diminished the quantity of CBN in the plant and thus, the

208 quantity archived in the sediment. Further studies are required to test such a hypothesis.

209 Considerable amounts of CBN were still detected throughout the $18^{\text {th }}$ century in our

210 samples, synchronous with maximal values of Cannabis pollen rates, despite a royal

211 ordinance dated A.D. 1669 that forbade retting in French rivers in order to preserve water

212 quality, fish stocks, and cattle health (Anonymous, 1772). This observation is in accordance

213 with historical documents, which indicate that this ban was never put into practice and was

214 still being debated $160 \mathrm{yr}$ later (Duvergier, 1830).

215 While the first occurrence of CBN does not correlate with the first occurrence of

216 Cannabis sp. pollen in sediments, the abundance of these tracers both strongly decrease in

217 sediments younger than A.D. 1860. On the worldwide scale, this period corresponds to the

218 development of the cheaper cotton industry (e.g., May and Lege, 1999) (followed by

219 synthetic textiles), which hastened the abandonment of textile hemp cultivation. 


\section{CONCLUSIONS}

222 Consistent with pollen analyses, the presence of CBN in Lake Aydat sediment

223 samples during the period of hemp cultivation in the region strongly suggests that this

224 compound - an unequivocal molecular biomarker of Cannabis sp.—can be used in

225 sediments as a sedimentary tracer of anthropogenic activity and pollution for archaeological

226 and paleoecological studies. In addition to pollen studies reflecting the cultivation of hemp,

227 our results indicate that $\mathrm{CBN}$ tracks more specifically the subsequent retting process, reputed

228 to significantly alter water quality.

229 Although further work is necessary to better evaluate the stability of CBN in older

230 sediments, this compound can be tracked in natural archives to reconstruct hemp retting

231 history and its induced pollution in a continuous time frame, as opposed to archaeological

232 studies classically performed on archaeological sites that are more constrained in space and

233 time, and can give reliable information about past impacts of human activities on the

234 environment.

\section{ACKNOWLEDGMENTS}

237 This study was supported by the ERODE project (Institut National des Sciences de

238 1'Univers, Centre National de la Recherche Scientifique). We thank the ARTEMIS program

239 for AMS radiocarbon dating, F. Arnaud (EDYTEM, Chambéry, France) for coring material

240 and participation on the field, J.L. Reyss for ${ }^{137}$ Cs measurements, and E. Chapron (ISTO,

241 Orléans, France) for his help for the depth-age model. Lavrieux also acknowledges the

242 Région Centre for her Ph.D. grant. 


\section{REFERENCES CITED}

245 Anonymous, 1772, Commentaire sur l'ordonnance des eaux et forêts, du mois d'août 1669:

246 Paris, Debure l'aîné, 516 p.

247 Brown, D.T., 1998, Non-medicinal uses of Cannabis sativa, in Brown, D.T., ed., Cannabis:

248 The genus Cannabis: Amsterdam, Harwood Academic Publishers, p. 115-124.

249 Bull, I.D., Lockheart, M.J., Elhmmali, M.M., Roberts, D.J., and Evershed, R.P., 2002, The

250 origin of faeces by means of biomarker detection: Environment International, v. 27, p. 647-654, doi:10.1016/S0160-4120(01)00124-6.

252 Charbonnier, P., 1980, Une autre France: La seigneurie rurale en Basse-Auvergne du XIV au $\mathrm{XVI}^{\mathrm{e}}$ siècle [Ph.D. thesis]: Clermont-Ferrand, France, University of ClermontFerrand, 1294 p.

Dearing, J.A., 2006, Climate-human-environment interactions: Resolving our past: Climate of the Past, v. 2, p. 187-203, doi:10.5194/cp-2-187-2006.

257 de Ballainvilliers, S.C.S.B., 1846, Etat de l'Auvergne en 1765: Clermont-Ferrand, France, $258 \quad$ Bouillet, $201 \mathrm{p}$.

259 de la Platière, R., 1784, Encyclopédie méthodique, Manufacture et arts, Tome second: Paris, $260 \quad$ Panckoucke, 315 p.

261 De Pasquale, A., Tumino, G., and Costa De Pasquale, R., 1974, Micromorphology of the 262 epidermic surfaces of female plants of Cannabis sativa L.: Bulletin on Narcotics, v. 26, 263 p. $27-40$.

264 Diderot, D., and d'Alembert, J.L.R., 1778, Encyclopédie, ou Dictionnaire raisonné des 265 sciences, des arts et des métiers, Tome septième: Geneva, Switzerland, Pellet, 894 p. 
266 Duvergier, J.B., 1830, Collection complète des lois, décrets, ordonnances, réglemens et avis 267 du Conseil-d'Etat (de 1788 à 1824 inclusivement, par ordre chronologique): Paris, 268 Guyot, Scribe et Charles-Béchet, 872 p.

269 ElSohly, M.A., and Slade, D., 2005, Chemical constituents of marijuana: The complex 270 mixture of natural cannabinoids: Life Sciences, v. 78, p. 539-548, 271 doi:10.1016/j.lfs.2005.09.011.

272 Faegri, K., and Iversen, J., 1989, Textbook of pollen analysis, 4th edition: Caldwell, New 273 Jersey, The Blackburn Press, 328 p.

274 Jacob, J., Disnar, J.R., Boussafir, M., Albuquerque, A.L.S., Sifeddine, A., and Turcq, B., 275 2005, Pentacyclic triterpene methyl ethers in recent lacustrine sediments (Lagoa do 276 Caçó, Brazil): Organic Geochemistry, v. 36, p. 449-461, 277 doi:10.1016/j.orggeochem.2004.09.005.

278 Jacob, J., Disnar, J.R., Arnaud, F., Chapron, E., Debret, M., Lallier-Vergès, E., Desmet, M., 279 and Revel-Rolland, M., 2008, Millet cultivation history in the French Alps as evidenced 280 by a sedimentary molecule: Journal of Archaeological Science, v. 35, p. 814-820, 281 doi:10.1016/j.jas.2007.06.006.

282 Lavrieux, M., 2011, Biomarqueurs moléculaires d'occupation des sols, du sol au sédiment: 283 Exemple du bassin-versant et du lac d'Aydat (Puy-de-Dôme) [Ph.D. thesis]: Tours, 284 France, Université François-Rabelais de Tours, 246 p.

285 Lavrieux, M., Jacob, J., Le Milbeau, C., Zocatelli, R., Masuda, K., Bréheret, J.G., and 286 Disnar, J.R., 2011, Occurrence of triterpenyl acetates in soil and their potential as 287 chemotaxonomical markers of Asteraceae: Organic Geochemistry, v. 42, p. 1315-1323, 288 doi:10.1016/j.orggeochem.2011.09.005. 
Lavrieux, M., Bréheret, J.G., Disnar, J.R., Jacob, J., Le Milbeau, C., and Zocatelli, R., 2012, Preservation of an ancient grassland biomarker signature in a forest soil from the French Massif Central: Organic Geochemistry, v. 51, p. 1-10, doi:10.1016/j.orggeochem.2012.07.003.

Lavrieux, M., Disnar, J.R., Chapron, E., Bréheret, J.G., Jacob, J., Miras, Y., Reyss, J.L., Andrieu-Ponel, V., Arnaud, F., 2013, 6,700-year sedimentary record of climatic and anthropogenic signals in Lake Aydat (French Massif Central): The Holocene v. 23, 1317-1328. doi:10.1177/0959683613484616

Le Milbeau, C., Lavrieux, M., Jacob, J., Bréheret, J.G., Zocatelli, R., and Disnar, J.R., 2013, Methoxy-serratenes in a soil under conifers and their potential use as biomarkers of Pinaceae: Organic Geochemistry, v. 55, p. 45-54, doi:10.1016/j.orggeochem.2012.11.008.

May, O.L., and Lege, K.E., 1999, Development of the world cotton industry, in Smith, C. W., and Cothren, J.T., eds., Cotton: Origin, History, Technology and Production: New York, John Wiley \& Sons, p. 65-98.

McPartland, J.M., and Guy, G.W., 2004, The evolution of cannabis and coevolution with the cannabinoid receptor-A hypothesis, in Guy, G.W., et al., eds., The Medicinal Uses of Cannabis and Cannabinoids: London, Pharmaceutical Press, p. 71-102.

Mercuri, A.M., Accorsi, C.A., and Mazzanti, M.B., 2002, The long history of Cannabis and its cultivation by the Romans in central Italy, shown by pollen records from Lago Albano and Lago di Nemi: Vegetation History and Archaeobotany, v. 11, p. 263-276, doi:10.1007/s003340200039. 
311 Miras, Y., Laggoun-Défarge, F., Guenet, P., and Richard, H., 2004, Multi-disciplinary

312 approach to changes in agro-pastoral activities since the Sub-Boreal in the surroundings

313 of the "narse d'Espinasse" (Puy de Dôme, French Massif Central): Vegetation History

314 and Archaeobotany, v. 13, p. 91-103, doi:10.1007/s00334-004-0033-z.

315 Pate, D.W., 1994, Chemical ecology of Cannabis: Journal of the International Hemp

$316 \quad$ Association, v. 2, p. 32-37.

317 Peuchet, J., 1800, Dictionnaire universel de la géographie commerçante, Tome quatrième:

318 Paris, Blanchon, 797 p.

319 Poitrineau, A., 1965, La vie rurale en Basse-Auvergne au XVIII ${ }^{\mathrm{e}}$ siècle (1726-1789) [Ph.D.

320 thesis]: Paris, University of Paris, 929 p.

321 Raman, A., 1998, The Cannabis plant: Botany, cultivation and processing, in Brown, D.T.,

322 ed., Cannabis: The genus Cannabis: New York, Harwood Academic Publishers, p. 29-

32354.

324 Russo, E.B., 2007, History of Cannabis and its preparations in saga, science, and sobriquet:

325 Chemistry \& Biodiversity, v. 4, p. 1614-1648, doi:10.1002/cbdv.200790144.

326 Schofield, J.E., and Waller, M.P., 2005, A pollen analytical record for hemp retting from

327 Dungeness Foreland, UK: Journal of Archaeological Science, v. 32, p. 715-726,

328 doi:10.1016/j.jas.2004.12.004.

329 Small, E., and Antle, T., 2003, A preliminary study of pollen dispersal in Cannabis sativa in

330 relation to wind direction: Journal of Industrial Hemp, v. 8, p. 37-50,

331 doi:10.1300/J237v08n02_03.

332 Whittington, G., and Gordon, A.D., 1987, The differentiation of the pollen of Cannabis

333 sativa L. from that of Humulus lupulus L.: Pollen et Spores, v. 29, p. 111-120. 
334 Wills, S., 1998, Cannabis use and abuse by man: An historical perspective, in Brown, D.T.,

335 ed., Cannabis: The genus Cannabis: New York, Harwood Academic Publishers, p. 1-27.

336 Zocatelli, R., Jacob, J., Turcq, B., Boussafir, M., Sifeddine, A., and Bernardes, M.C., 2010,

337 Biomarker evidence for recent turf cultivation in Northeast Brazil (Lagoa do Boqueirão,

338 RN State): Organic Geochemistry, v. 41, p. 427-430,

339 doi:10.1016/j.orggeochem.2009.12.008.

340

$341{ }^{1}$ GSA Data Repository item 2013209, Table DR1 (Cannabis-type and Cannabis-Humulus-

342 type pollen counts), is available online at www.geosociety.org/pubs/ft2013.htm, or on

343 request from editing@geosociety.org or Documents Secretary, GSA, P.O. Box 9140,

344 Boulder, CO 80301, USA. 